\title{
Three Arabic letters from North Sumatra of the sixteenth and seventeenth centuries
}

\author{
A.C.S. Peacock
}

\begin{abstract}
This article examines three Arabic documents, one from the Sultanate of Samudera-Pasai dated 1516, and two from the Sultanate of Aceh, dated 1602 and 1603, written in the name of Sultan Alauddin Riayat Syah (r.1589-1604). The Samudera-Pasai document represents the earliest surviving manuscript in the Arabic script from Southeast Asia, while the second and third letters are some of the earliest documents that have come down to us from the Aceh sultanate. Despite their historical importance, these documents have not previously been adequately published. This article presents an analysis from a diplomatic, stylistic and philological point of view, comparing them with Malay and Middle Eastern epistolary traditions and examining the significance of the use of Arabic. It also considers the light they shed on diplomatic practice in early modern North Sumatra. An edition and modern English translation of the documents are presented in an appendix, along with a contemporary Portuguese translation of the Pasai letter and the translation by the English Arabist William Bedwell (1561-1632) of the Aceh letter of 1602.
\end{abstract}

\section{KEYWORDS}

Arabic; Sumatra; diplomatics; Samudera-Pasai; sultanate of Aceh.

The written heritage of Muslim Southeast Asia is well known through texts in Malay, Javanese and other local languages. As in the rest of the Muslim world, Arabic has always been an essential language for religious learning, and has also played an important role as the principal language of Muslim epigraphy. In Southeast Asia, Arabic epigraphy is largely restricted to funerary monuments, and its use may thus be seen as a result of its function as a religious language. Qur'anic verses predominate in such inscriptions, fine examples of which exist in abundance in northern Sumatra, especially around Lhokseumawe and in Banda Aceh itself. Such tombstones, often commemorating local rulers, their families and officials, can also serve as historical sources in their own right, as has been demonstrated by recent research in northern Sumatra that has revised our understanding of the early Muslim sultanate of Pasai (Guillot and Kalus 2008).

Yet Arabic was never purely a religious language. Although unquestionably the bulk of literature in Arabic produced and read in Southeast Asia was and is religious, or else designed to help students of Islam, such as Arabic grammar books, ${ }^{1}$ Arabic also played a role as a language of diplomacy and statecraft more generally, alongside Malay, Javanese, Portuguese, and on occasion Persian. Especially from the 19th century, we have a rich vein of correspondence in Arabic addressed to the Ottoman sultan, sent by, among others, the rulers of Aceh, Kedah, and Jambi. These documents serve not just as sources for Southeast Asian

${ }^{1}$ For remarks on these aspects of Arabic in Southeast Asia see Johns (1996) and Ricci (2011); see also Vrolijk (2015: 284-6). 
history, but also offer new perspectives on diplomacy and chancery practice in the region and help us understand Southeast Asia's connections with the broader Islamic world. ${ }^{2}$

Arabic chancery documents also survive, albeit in much smaller quantities, from earlier periods, but remain very little known. There are two principal, if small, corpuses of Arabic documents: those from the North Sumatran sultanates of Pasai and Aceh dating to the 16th and early 17 th centuries, and those from the sultanate of Banten in Java, dating to the 16th century. I shall concentrate here on three North Sumatran documents and will also refer briefly to the Banten corpus for comparative purposes. Among the documents under consideration is a letter from the Sultan of Samudera-Pasai composed around 1516, which is especially significant as it pre-dates the earliest extant Malay Arabic-script manuscripts from the region and is the oldest Arabic-script document to survive from Southeast Asia (Gallop 2015: 19). ${ }^{3}$ The other two documents come from early 17 th-century Aceh, which represent some of the oldest surviving documents from the sultanate.

All three letters have been published in some form previously, but they have not received the attention their importance warrants, and the previous publications are often seriously deficient in their understanding of the texts. I offer a discussion of the principal linguistic and stylistic features of these documents, with the full text and translation presented in an appendix. I will seek to address two questions in particular: what was the relationship of the Arabic documents to contemporary ones in Malay; and what affinities do they have with Middle Eastern chancery practice? Later Arabic epistolography from Southeast Asia as attested in 19th century examples is often characterised by an attempt to adhere to Middle Eastern, often specifically Ottoman, forms of chancery practice, in terms of the choice of titulature, greetings and the use of elevatio (Gallop 2007 and Gallop et al. forthcoming). A study of the earliest known evidence promises to shed light on the origins of these practices. In the conclusion I will comment on the reasons for the use of Arabic in these documents.

We are dealing with a very small corpus of documents that has survived and the answers presented here are very tentative indeed. Moreover, all the extant Arabic letters from the 16th and 17th centuries come from European collections. More were certainly produced for other audiences. Several Acehnese embassies to Constantinople are attested, and Banten also had a close relationship with the Sharif of Mecca from whom its sultans sought legitimation of their rule. ${ }^{4}$ In both instances the embassies undoubtedly brought with them letters which are now lost to us, and it seems highly likely these would have been in Arabic. However, the doubtless much more extensive correspondence between Southeast Asia and other Muslim rulers has not survived, with one partial and problematic exception. The Topkap 1 Palace Museum in Istanbul holds a Turkish-language letter dated 1565 which purports to be from the ruler of Aceh, Alauddin Riayat Syah al-Kahar (r.1537-1571), to the Ottoman sultan Süleyman the Magnificent, but the text in its current form certainly does not seem to be a product of the Acehnese chancery, if there was such a thing (see Casale 2005). Thus our limited corpus of documents addressed to Europeans may not be entirely representative of epistolary traditions in general. Furthermore, until the 18th century, the corpus of Malay letters with which to compare these is quite limited too, although there is enough to suggest that at least by the early 17th century the tradition of Malay epistolography and the format of the letters had become established in something resembling its classical form (Gallop 2003a: 404). In addition, there was more than one way of writing a letter in the Middle East, although the conventions of letter

${ }^{2}$ For an edition and translation of correspondence between Southeast Asia and the Ottoman Empire see Kad and Peacock forthcoming. For a detailed study, edition and translation of one set of such documents from the mid-19th century, see Kadi et al. (2011).

${ }^{3}$ The next oldest document is a letter in Malay from Ternate dated 1521, see Blagden (1930). For a survey of Southeast Asian materials from the seventeenth century in European collections see Vrolijk (2015: 286-291).

${ }^{4}$ On Aceh and the Ottomans, see Reid (1969); on Banten's relationship with Mecca see van Bruinessen (1995). 
writing in the early modern Middle Eastern empires - the Mamluk, Ottoman and Safavid shared many points in common, such as mutually comprehensible conventions of courtesy, expressed both through the language and format of the documents (see Broadbridge 2008: 1622; Busse 1959; Gökbilgin 1979; Ménage 1985; Reinfandt 2013; Gallop et al. forthcoming).

\section{The letter of Zayn al-'Abidin IV, Sultan of Pasai, $1516^{5}$}

Our oldest Arabic letter appropriately comes from Pasai, the North Sumatran sultanate (14thearly 16th centuries) whose long connections with the Middle East are attested by numerous early sources, by local epigraphic traditions, and indeed by the ancestry of the local elite. ${ }^{6}$ One prominent local family in the 14th century claimed descent from the 'Abbasid Caliphs, and intermarried with the family of the Malay sultans whom they probably served to legitimise. The founder of the sultanate of Pasai (c.1297?) adopted a title reminiscent of the Ayyubid rulers of Syria, al-Malik al-Salih, while the Mamluk-sounding laqabs (titles) al-Malik al-Zahir and al-Malik al-Ashraf were also in use there. Tombstones of members of the elite record links to the Middle East through nisbas (names denoting origin) like Irani and Gilani, while the Turkic title khan also became popular in Pasai (Guillot and Kalus 2008: 184, 299). The Sejarah Melayu tells us when recording the origins of the sultanate of Pasai that 'at that time all the people of Pasai knew Arabic' (Brown 1970: 36, and further on Arabic in Pasai see Braginsky 2004: 116-18). The legendary history of the rulers of Pasai attributed to them descent from the Caliph Abu Bakr, and both the Sejarah Melayu and the Hikayat Raja Raja Pasai contain many allusions to Pasai's links with India and Arabia. Naturally, these stories serve to emphasise Pasai's credentials as a centre of Islamic civilisation, but they may not have been wholly mythical. When Ibn Battuta visited Pasai in the mid 14th century, he had no difficulty in communicating, presumably in Arabic. ${ }^{7}$ By the 1420 s the elaborate gravestones which are the greatest surviving monuments of medieval Pasai, replete with finely carved Arabic inscriptions, were being produced locally (the earlier exemplars being imports from India; Lambourn 2004). However, Guillot and Kalus (2008: 124) have suggested that competence at Arabic had declined by the mid to late 15 th century. This opinion is certainly borne out by the letter under consideration here.

The letter itself has no date, but internal evidence suggest it must have been composed in 1516 or at the latest, early 1517, and was addressed to Afonso de Albuquerque, governor of the Portuguese Estado da Índia, and comprises a complaint about the activities of two Portuguese privateers, Manuel Falcão and Gaspar Magalhães. As the historical circumstances in which the letter was written and the activities of these individuals have been examined by Alves (1999: 91-7, 189-90) in detail, we shall not discuss them here. However, the date of the document requires explanation. The date is suggested by reference to the misdeeds of the Portuguese privateers, which occurred in mid to late 1516, while Zayn al-'Abidin IV's end came in February $1517 .^{8}$ The sultan was evidently unaware that Albuquerque had in fact died in 1515 , being replaced by Diogo Lopes de Sequeira. The printed edition of the Arabic text prepared by dos Santos and published in 1790 contains striking differences from the manuscript. Not only have many of the most difficult textual readings been removed, but the

\footnotetext{
${ }^{5}$ Arquivo Nacional Torre do Tombo, Lisbon, Colecção de cartas, Núcleo Antigo 891, mç. 1, Doc. No. 59; for further references see note 18 below.

${ }^{6}$ Guillot and Kalus (2008: 57-135) for a summary of what is known of the history and society of Pasai in this period.

${ }^{7}$ Guillot and Kalus (2008: 124, 124-6) for a general consideration of the linguistic situation in Pasai.

${ }^{8}$ For the dates see the remarks in Gallop (2015: 19, n.8); I am also grateful to Jorge Santos Alves for his comments.
}

Commented [PK1]: Check names and spelling - are they the same two names highlighted above? 
printed text provides a date - Sha'ban 926, corresponding to 21 July 1520 . This would date it to the reign of Zayn al-'Abidin V of Pasai, who ruled from 1519 to 1521, but it is not congruent with the information provided within the letter. To complicate matters, the Portuguese translation given by dos Santos provides the date of 916, corresponding to 1510. It is clear, however, that neither the Portuguese translation nor the printed Arabic text are reliable sources for the contents of the letter, as the translation is littered with obvious mistakes, suggesting that dos Santos struggled to make sense of even basic words in the original. In addition further differences are exhibited by another, unpublished and undated early modern Portuguese translation of the letter, which seems to have been done at Malacca in 1516-17), where the translator made various additions, omissions and alterations to the contents. The present discussion is thus based on the manuscript Arabic text, not on the edition which seems to have no value as a witness to the text. The 1516-17 Portuguese translation, however, is useful clarifying some obscure words in the Arabic text, and is therefore presented in the Appendix to this article.

The language of the letter is simple, terse, and frequently obscure. In several instances the Arabic text contains borrowings from Malay or Portuguese, which would not be readily comprehended without some knowledge of those languages. The recipient is addressed as kaptān mūr, an Arabic transcription of Albuquerque's title capitam mor, Captain-General. In line 21 qala ${ }^{\prime}$, apparently the Malay kaling, meaning tin or pewter is used, and there are several other words, as noted in the edition of the text given in the Appendix, which are certainly not Arabic and cannot be readily understood today, such as لبستيخ (1. 12) for which I am not able to offer an explanation. The Malay letter $\stackrel{\oplus}{\text { for }} p$ appears in several words: kaptān (captain) (1.1), Kaspar (Caspar) (1. 14), al-Palyakāt (the port of Pulicut) (1. 17), Purtukāl (Portuguese) (1l. 4, 24, 26; the first usage in 1.2 is unpointed). Such a usage is unknown in Arabic where $p$ would usually be rendered with $\varphi\left(b \bar{a}^{\prime}\right)$. Grammatically, the text strays from the rules of classical Arabic. Gender agreement is not observed (e.g. line 3, fariha qulübunā, recte farihat qulübuna), while the grammar of line 10 is sufficiently incoherent to obscure the meaning. It is far from clear who is the subject of the verb qatalahu, Manuel Falcão (as the Portuguese translation of 1516-17 suggests) or the four men who are mentioned (as grammar would require). Whether these four men are associates of Manuel Falcão or the governor of Samudera is also unclear.

Overall, the letter has a colloquial feel, and is singularly lacking in elaborate rhetorical formulae. Compared to later Malay letters from Aceh - or Arabic ones for that matter - its incipit is terse: 'From Zayn al-Din who upholds the affairs of the Lord of both worlds to the Captain-General who [resides] in the fortress of the sultan of Portugal, to whom governance of the land is attached.' What was to become the Malay convention of naming both the sender and recipient is observed, in contrast to the common practice in Middle Eastern royal letters addressed to an inferior of naming only the recipient. Yet the phraseology seems intended to suggest Zayn al-'Abidin's superiority to both the recipient and the latter's master, the king of Portugal. While Zayn al-'Abidin is the upholder of God's affairs, 'government of the land' is merely 'attached' to the Portuguese king. This contrasts with latter Malay epistolic traditions in which the recipient was conventionally given more elaborate attributes than the sender (cf. Gallop 2011: 133). These can be observed even in the near contemporary letters from Ternate in the Moluccas, the earliest surviving Arabic-script Malay documents. That of 1521 starts, 'Letter of Sultan Abu Hayat to his uncle the King of Portugal, the (great ?) king of the whole world, the great lord', while that composed the following year commences, 'This is a loving letter of Sultan Abu Hayat, a letter to his father, the King of Portugal, he is the greatest in the world' (Blagden 1930: 92-3, 95-6).

For a royal letter, the Pasai manuscript is surprisingly lacking in any formal attributes such as seal or opening invocation as are found in the earliest Malay letters from north Sumatra, although these are a good century later in date (cf. Gallop 2011: 131). In contemporary practice 
in the Middle East, royal letters were generously spaced, finely calligraphed and written on expensive paper (cf. Broadbridge 2008: 16-22). How should the Pasai letter's formal features (or their absence) be interpreted? Does the cramped inelegant $t a$ ' $l \bar{l} q$ hand in which the Pasai letter is written, its absence of any decorative elements, and the extreme simplicity of its greetings suggest that the very lack of formal features was intended as a reproof to the recipient? This has been argued for later letters in Malay from Banten (Gallop 2003a: 403), and would suit the subject of the letter, which is a complaint. On the other hand, Zayn al-Din's letter is at pains to be conciliatory, stressing that the sultan did not believe that either the Portuguese king or Albuquerque was aware or approved of the activities of the Portuguese privateers (11. 24-26). It seems most likely that the absence of formal elements in the letter reflects two facts: firstly, that the recipient is not himself a king, and therefore it is not an example of 'royal to royal' correspondence; and in addition, in all likelihood, indicates Pasai's remoteness from the Middle Eastern centres of Islamic civilisation and the conventions of their chanceries. Taken together with the provincial style of the Arabic, the letter is more reminiscent of a note exchanged between merchants at a busy port rather than the product of a chancery with any degree of sophistication.

\section{The letter of Alauddin Riayat Shah of Aceh of 1602}

In 1602 an English trade mission under Sir James Lancaster reached Aceh, the North Sumatran sultanate that during the 16th century had inherited the mantle from Pasai of being the leading centre of Islamic culture in Southeast Asia. ${ }^{9}$ As a result of Lancaster's efforts, two Malay trading permits were issued, as well as a letter addressed to the English monarch. This latter was written in Arabic, and is the second oldest extant example of an Arabic diplomatic missive from Southeast Asia. Only the second half of the Arabic text has been preserved in a copy that seems to be in the hand of William Bedwell, the English Arabist. Bedwell's English translation serves as the sole evidence for the full text of the letter (Shellabear 1898: 108; Foster 1940: 111). Unfortunately, Bedwell's Arabic was not that good. His real interest was in the Christian gospel in Arabic, and parallels between Hebrew and Arabic as he was to be one of the translators of the King James Version of the Bible into English. He also produced a dictionary of Arabic where the words are glossed according to their Biblical usage. ${ }^{10}$ This meant that Bedwell stumbled even when confronted with some quite basic words in the letter from Aceh. The manuscript of his translation of the letter contains glosses on some of the words he found worthy of comment. Bandar for example, threw him completely, even though it is a fairly common post-classical Arabic word for port, a loanword from Persian. Bedwell thought bandar was the plural of banda which 'signifieth ... a country or a territory' in 'the language of Samuddara' (see Appendix 2a). A close comparison of the surviving parts of the Arabic text confirms he often had a shaky grasp on the exact meaning although the general contents of the letter are conveyed. ${ }^{11}$ This means we can only use his translation as a source for the missing portions of the Arabic text with a degree of caution. However, the marginal comments on his translation do give some clue as to the Arabic vocabulary used in the lost parts of the text.

${ }^{9}$ For Islamic culture in Aceh in this period, see Hadi (2004: 148-52); for the Lancaster mission see Foster (1940).

${ }^{10}$ On Bedwell and his studies of Arabic see Hamilton (1985).

${ }^{11} \mathrm{Cf}$. the comments of Gallop on a 17th-century English version of a Malay letter dated 1661 from the Acehnese ruler Sultana Taj al-'Alam Safiyyat al-Din Syah to Charles II: 'The gist of the contents is quite accurate ... However all nuance and sense of balance is lost, and many of the compliments for the king and the English in the translation are not found in the original Malay' (Gallop 2011: 128). 
The letter starts with elaborate praise of God. Although the recipient is named as 'the sultan which dothe rule in England, France, Holland and Fransuzze' the sender is mentioned only obliquely. Indeed, that the letter was sent on behalf of the Acehnese sultan can only be inferred from the text. As in the case of the Pasai letter, the Acehnese side preferred to emphasise their status not through directly competing with titles but through invoking divine support. In the omission of a direct mention of the sender, the 1602 letter reflects Middle Eastern diplomatic practice (Ménage 1985: 289; Gallop 2011: 132-3). In contrast, the trading permits in Malay written in the same year start with a direct mention of the Acehnese ruler: alsultan Alauddin Syah berfirman ... or the more strident form Aku raja yang kuasa yang di bawah angin ini ... (Shellabear 1898: 121-2), and standard practice in Malay 'royal to royal' letters would be to name both sender and recipient, with politeness requiring that the recipient be showered with elaborate compliments although this convention was sometimes broken as a deliberate discourtesy (Gallop 2011: 132-3).

The language of this letter differs considerably from that of Zayn al-'Abidin's missive. In place of the simple language of the latter, the author of the Acehnese letter strives for stylistic elegance, in particular the use of rhyming prose and parallelism. This insh $\bar{a}$ ' style had long been considered a characteristic of elegant Arabic epistolography, so we find phrases like mu'akkidan bi-dhālika al-masțūr fi hadhā al-șudūr ('affirming with this letter its promulgation') and tazayāda surūrunā wa-takāthara hubürunā ('our happiness was increased and our delight multiplied'). The effect is marred, however, by the numerous grammatical errors, in particular a failure to observe masculine/feminine agreement. As this sometimes is key to the rhymes, it evidently derives from the original text and not from Bedwell's deficiencies as an Arabist: thus bi-l-ri 'âya al-tāmm ... al-uns wa-l-ikrām (correctly should read tāmma). There are a number of other grammatical errors, but the lack of gender agreement strongly suggests the letter was produced by a native Malay speaker. It was certainly not produced by a native speaker of Arabic, and there are some Malayisms in the text, such as the use of kaptan instead of $r a ' \bar{l} s$ and the use of the Jawi letters 3 (p) and है (ng).

In short, the letter was written by someone who knew what an elegant Arabic letter should look like, but was insufficiently expert to produce one properly himself. The Middle Eastern courtesy of naming the recipient but not the sender is observed, and the rhymed prose of elegant Arabic style is imitated - badly. The author was not sufficiently well acquainted with Arabic to be able to replicate the insh $\bar{a}$ ' letters of which he must have had experience whether through incoming ones to the Acehnese chancery or through insh $\bar{a}$ ' manuals, we do not know. Given the writer was in all likelihood a local of Aceh or at least the Malay world, it is all the more interesting that the letter differs so greatly from the conventions of Malay epistolography.

\section{The letter of Alauddin Riayat Syah of 1603}

Some of these impressions are confirmed by the Arabic letter sent by Sultan Alauddin Riayat Syah, dated Shawwal 1011/March 1603, to the Dutch ruler, the Stadtholder, Prince Maurice. The letter mentions the arrival of the expedition of Admiral Joris van Spilbergen with gifts and letters for the sultan, and was written on the occasion of their departure, to accompany the gifts of pepper Sultan Alauddin sent to Prince Maurice. ${ }^{12}$

The letter is written in a simple style, mentioning neither sender nor recipient. It is perhaps this feature which has led to it being described as an 'exit permit' (Wassing-Visser

${ }^{12}$ For details of Acehnese-Dutch connections during this period, see Wassing-Visser (1995: 28-37), with a translation and photograph of the letter on pp. 34-5. For further discussion of the use of Arabic in DutchSoutheast Asian relations in the seventeenth century see Vrolijk (2015).
Commented [PK4]: Please confirm this is sic. 
1995: 34; Gallop 2011: 131). However, the addressee of the letter is clearly not van Spilbergen, but Prince Maurice who is referred to with the second person pronoun in lines 10-11 (a fact obscured by the English translation published by Wassing-Visser). Thus this is not an exit permit but a royal letter to another monarch accompanying gifts of spices. Nonetheless, the absence of direct mention of either sender or recipient is curious. It may reflect the fact that while addressed to another sovereign, the document is intended to be a note or confirmation of a treaty, as is suggested by its opening (11. 2-3). Alternatively, the absence may reflect uncertainty as to Prince Maurice's exact status, although as mention is made of a treaty 'between sultans', implying equality with the sultan of Aceh it was evidently felt to be roughly comparable to the sender's. Dutch merchants went to some efforts to gloss over Prince Maurice's complicated constitutional position as Stadtholder and portray him as a monarch (Wassing-Visser 1995: 30). In contrast to Malay royal letters of the 17th century to European rulers where the seal is generally placed towards the top of the right hand margin, in the 1603 letter the seal is placed towards the bottom, perhaps in courteous imitation of Maurice's own practice. ${ }^{13}$

In contrast to the 1602 letter to Elizabeth, the language is unadorned. Linguistically, the Arabic reads rather more fluently than in the previous two examples, although there are still a number of solecisms and Malayisms (e.g. kaptan كفتن for Captain; the clause starting wa huwa fi mamlakat Ashi on 1l 3-4 relates awkwardly to what has preceded it; as in the 1602 letter, the date is given $f i$ ' adad al-islām rather than the more common formula fi sanat xxx al-hijriyya or "nabawiyya).

We are fortunate that, unlike the 1602 letter, the original manuscript of the letter to Prince Maurice has survived, and is one of the earliest extant documents from the Aceh sultanate. The formal aspects of the letter confirm the impression given by the 1602 missive of the development (or presence) of a chancery that sought to conform to Middle Eastern practice. The letter is generously spaced, occupying only the bottom half of a sheet of paper. At very top comes a letter heading, the divine invocation huwa. This was a common feature of Middle Eastern correspondence and other 17th-century Malay letters from Aceh, but not the rest of the Malay world (Gallop 2011: 131). The letter itself commences with an invocation of God, reminiscent of that recorded in Bedwell's English translation of the 1602 letter, but conspicuously absent in the Pasai letter.

Many of these aspects present a striking contrast to the surviving Malay letters from 17th-century Aceh. Although both share the invocation huwa at the top, Malay letters open with extended descriptions of the might and power of the sender, which are completely absent here. While the Arabic letter of 1603 is generously spaced but on plain paper, the surviving Malay royal letters, of which the earliest is that dated 1615 addressed to James I, tend to be lavishly illuminated and much larger (Gallop 2011 passim). Finally, as Gallop has noted in her study of Alauddin Riayat Syah's seal, this too exhibits considerable Ottoman influence in its decorative motifs (Gallop 2004).

\section{Conclusions}

In terms of style and form, the Pasai letter differs from the two Aceh letters. This is unsurprising given the passage of nearly a century and the fact that, unlike the Aceh letters, the Pasai one is not addressed to a fellow monarch. Nonetheless, it is striking that the Pasai letter exhibits none of the key characteristics of the Aceh letters; the latter show clear affinities to Middle Eastern epistolary traditions, in language (the use of insh $\bar{a}^{\prime}$ and initial invocation), compliments

${ }^{13}$ For Prince Maurice's seal, see Wassing-Visser (1995: 29); I am grateful to Annabel Teh Gallop for this point. Cf. Gallop and Porter (2012: 46-51); for reproductions of the Malay letters see Gallop (2011: 108, 114, 125). 
(absence of mention of the sender), and form (generous spacing of the letter, absence of illumination and the decorative elements on the seal of the 1603 letter). These factors all place the Acehnese letters somewhat apart from the Malay letter-writing traditions, as attested both in documents from the Malay world more generally, and specifically the Acehnese ones of which the earliest is that of ultan Iskandar Muda to James I dated 1615 (see Gallop 2011).

The Pasai letter is intended purely as a practical document, as an enumeration of the crimes of the Portuguese privateers. Its provincial, Malay- and Portuguese-influenced vocabulary, and its absence of adornment or seal suggest this was not a letter trying to impress anyone with its language or appearance. In this instance, the use of Arabic was probably dictated simply by the fact that this remained the most widely spoken lingua franca of the Indian Ocean world, the most convenient way of communicating with the Portuguese in Goa. Why Malay was not chosen must remain a subject for speculation. The letter would have passed from Pasai to Portuguese-occupied Malacca where presumably Malay translators were easily found, and other Southeast Asian rulers of the period, such as those of Ternate, chose Malay as their lingua franca. The use of Arabic is thus suggestive of Pasai's closer links to the western Indian Ocean. However, the use of Arabic in the Alauddin's letters to Elizabeth and Maurice may be more significant, contrasting with the Malay used for Lancaster's trading permit as a more appropriate language for royal correspondence.

To draw firm conclusions on the basis of such a limited corpus is dangerous, but it seems possible to speculate that the choice of language for royal letters had a certain significance, with Arabic being preferred for messages of grave importance and/or positive content. In contrast, the Malay royal letters from Aceh are all essentially negative: the Malay letter of Iskandar Muda of 1615 is a rejection of English requests to trade; the Malay letter of Iskandar Thani of 1639 is a rejection of Dutch requests for assistance; and although Taj al'Alam Safiyyat al-Din's letter to Charles II of 1661 is superficially more positive in tone, it apparently elicited a cool reception from the English East India Company, whose directors described the accompanying gifts as 'dispicable' (Gallop 2011: 104-7, 114-6, 124).

These letters from North Sumatra bear comparison with the rather more extensive corpus from Banten addressed to the English kings James I and Charles II, now preserved in the UK National Archive (TNA). As the correspondence has been published in detail ${ }^{14}$ I shall here restrict myself to some brief comments. There are letters to James I dated 1605, two letters to Charles II dated 1664, one from 1680, one from 1681, and two dated 1682, in addition to several letters in Malay sent to both the English and Danish kings. ${ }^{15}$ The letters show a remarkable development in language and style. The earliest letter to James I is written in a very broken, at times almost incomprehensible Arabic, influenced by Javanese word order, and in structure is close to the norms of Malay writing. Even some of the terminology is Malay not Arabic: surat is used in place of risāla or kitāb for letter. The letters of 1664 and the $1680 \mathrm{~s}$ are very different both in formality and style. The Arabic here is generally free of grammatical solecisms, and while the style can hardly be described as elegant - there is no attempt to emulate insh $\bar{a}$ ' as in the Acehnese letter of 1602 - it is at least clear. Nonetheless, these documents are rather closer to the Malay epistolographic tradition than the Middle Eastern one, and the Arabic letter of 1681 is written on illuminated paper - the only one of the Banten letters

\footnotetext{
${ }^{14}$ Pudjiastuti (2007) offers facsimiles and Indonesian translations of the letters; see also Gallop (2003b), which includes a transcription and translation of some of the Malay letters from Banten, but not the Arabic ones.

15 The dates of some of the letters given by Pudjiastuti (2007) reflect the date of arrival rather than composition. Here we will refer to them by the date of composition to allow a more precise comprehension of their historical circumstances. TNA, CO 77/14, f. 38, from sultan Abu 1-Fath to Charles II, is dated awā'il dhì l-hijja 1091; Dhu 1-Hijja in this year began on 23 December 1680. TNA, CO 77/14, f. 111 is not dated but must have been sent with the embassy of Banten that reached London in April 1682. The embassy left Banten on 10 November 1681. See Jones (1982: 10).
} 
to be so. It is perhaps significant that there is a particular flurry of Arabic writing around 16801682 , as these were years of turmoil in Banten with rival contenders for the sultanate, Abu 1Nasr and his son Abu 1-Fath, seeking English support against each other and against the Dutch. ${ }^{16}$ These letters are desperate requests for aid and arms, despite their sometimes elaborate formal features.

Clearly, a hard and fast rule cannot be imposed; practical considerations must also have at times influenced choice of language. There is no evidence of large or developed chanceries, so in part language choice may have come down to what competent scribes were at hand. However, given the significance of aspects of epistolography such as forms of address, titulature, format, seal, all of which could indicate friendship or hostility, it seems reasonable to assume that choice of language could, at least in some times and places, also form part of the broader meaning and tone of the letter and have a significance in its own right. Such an explanation would also go some way to explaining why in both Aceh and Banten Arabic was used even when the writers evidently had an inadequate grasp on the language. In this connection it is worth considering further how these letters were composed. Leading members of the ulama seemed to have played an important role in diplomatic encounters with foreigners, in part because of their mastery of Arabic. The chief diplomat and politician of Aceh in the early 17 th century is generally considered to have been the noted mystic Shams al-Din, probably the man referred to by James Lancaster as 'the chiefe bishope of the realme' (Foster 1940:96). Lancaster comments favourably of his Arabic, and that of another nobleman with whom he had dealings:

A day and a meeting was appointed, where many questions passed betwixt them. And all the conferences passed into the Arabicke tongue, which both the bishop and the other nobleman well understood.

(Foster 1940: 96)

Shams al-Din's extant Arabic works confirm his mastery of Arabic, and their phrasing is usually lucid and felicitous. ${ }^{17}$

Gallop (2011: 112-3) has pointed to evidence for Shams al-Din's intimate involvement not just with the negotiations with foreign traders, but also with the preparation of royal letters. The granting of a royal letter was no small thing, but was accompanied by great pomp and ceremony (Gallop and Kratz 1994: 113-15). Yet this scholarly involvement must have still been limited. It is impossible to imagine a reputable arabophone scholar such as Shams al-Din having had any role in the composition of these letters with mistakes, provincialisms, and infelicities we see in the Acehnese Arabic missives. Thus we are presented with the curious conundrum that although it was thought necessary to choose a prestige language, Arabic, to communicate a positive message to another sovereign, and to do so with a superficial attention to elegant style, it was done in a remarkably slipshod way. In this sense the actual contents of the letter may have been seen as secondary to the very fact of its existence and the message conveyed by its formal aspects.

\section{Appendix: Texts and translations}

\footnotetext{
${ }^{16}$ A brief account with references to Dutch sources is given in Atsushi (2006: 17-18).

${ }^{17}$ See the texts in van Nieuwenhuijze (1945), and his evaluation of his competence at Arabic (1945: 31-2). His opinion has recently been repeated in Wormser (2014: 12). See also Vrolijk (2015: 287).
}

Commented [PK6]: Source and page no. of quote? Foster 1940 ?

Commented [PK7]: Not in References 
In presenting the Arabic texts, the original spelling, however irregular, has been maintained, and vocalisation and tashdì $d$ are given only when found in the manuscripts. However, $t \bar{a}^{\prime}$ marbut $t a$ has been given consistently in the form $\mathrm{o}$ for the purposes of clarity.

(1) The letter from Sultan Zayn al-'Abidin IV of Samudera-Pasai, 1516 (Figure 1). ${ }^{18}$ (a) Transcription of Arabic text

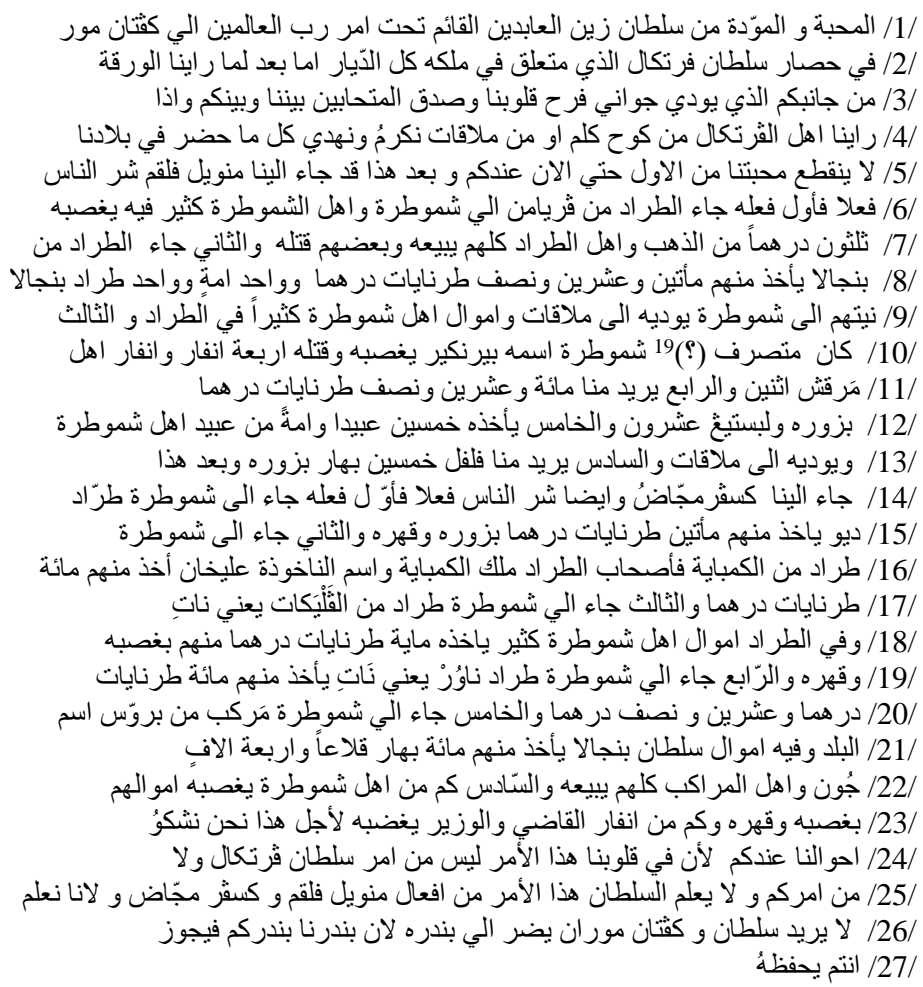

(b) Translation of the Arabic text by A.C.S. Peacock

\footnotetext{
${ }^{18}$ Arquivo Nacional Torre do Tombo, Lisbon. Colecção de cartas, Núcleo Antigo 891, mç. 1, n. ${ }^{\circ}$ 59. Previous publications: Arabic text and Portuguese translation with significant differences from that pre sented here in do Santos (1790: 127-30); translation only reprinted with additional notes in Alves (1999: 228-30); Arabic text with a number of differences from that presented here and Indonesian translation in Muhammad (2013). Taqiyuddin Muhammad's text is based on a poor quality image of the letter which accounts for most of the variations between his text and mine. It has not therefore usually been thought useful to record his variant readings. Help has also been provided by the Portuguese translation probably made in Malacca in 1516-17, presented in full in Appendix 1c. Although the translation is often imprecise, omitting crucial elements of the Arabic and sometimes supplementing it with additional information, it has the advantage that the tran slator was himself aware of the events referred to; it can therefore help clarify the frequently obscure Arabic text. ${ }^{19}$ The correct reading of this word is unclear. The Portuguese translation suggests the word must refer to some sort of senior official. The reading mutașsarif suggested here must be regarded as highly speculative.
} 
[Greetings of] affection and friendship from Sultan Zayn al-'Abidin, ruling subject to God's command, to the capitam mor [i.e. Governor-General ${ }^{20} / 2 /$ in the fortress of the king of Portugal to whose dominion all lands are dependent.

When we saw the letter $/ 3 /$ from your side which Giovanni ${ }^{21}$ brought, our hearts rejoiced, and the peace makers between our two sides were proved right. When $/ 4 /$ we see a Portuguese from Cochin (?) or Malacca, we honour him and give him all we have in our land. 15/ Our affection for you has not been interrupted from the start till now, [but] after this came Manuel Falcão, the worst of men in his deeds. His first deed: a tarrā $d^{22}$ came from Priaman to Samudera, with many people from Samudera on it. ${ }^{23} \mathrm{He}$ seized /7/ thirty gold dirhams and sold all the people on the ship, killing some of them. His second [deed]: there came /8/ a tarrād [from] Bengal, from which he took two hundred and twenty and a half tornayat ${ }^{24}$ of dirhams and one slave girl; one Bengal tarrād /9/ which was intending to make for Samudera he diverted to Malacca; much wealth of the people of Samudera was on the tarräd. His third [deed]:/10/ he seized the governor (?) of Samudera called Birankir ${ }^{25}$ and four of his men killed him, ${ }^{26} / 11 /$ and two from the people of the frontier (?) ${ }^{27}$ His fourth [deed]: he demanded from us one hundred and twenty and a half tornayat of dirhams /12/ by force and twenty $[\ldots] \cdot{ }^{28}$ His fifth [deed]: he took fifty slaves and slave girls from the people of Samudera's slaves /13/ and brought them to Malacca. His sixth [deed]: he demanded from us fifty bahar of pepper by force. ${ }^{29}$

After this, /14/ there came to us Gaspar Machado [Magalhaes], also the worst of men in deeds. His first deed: there came to Sumatra a tarrād /15/ from Diu, from which he took two hundred tornayat of dirhams by force. His second [deed]: there came to Samudera a tarrād from /16/ Cambay owned by the king of Cambay. The captain's name is 'Alikhan. He took

${ }^{20}$ The contemporary Portuguese translation confirms this reading: pera o capitam mor Eu estou neste castelo ...

${ }^{21}$ According to Alves (1999), Giovanni da Empoli may be meant, who was sent by Albuquerque to establish the Portuguese factory in Sumatra.

${ }^{22}$ Tarrād, a small but fast ship: see Agius (2002: 190)

${ }^{23}$ Priaman is in southwestern Sumatra, Minangkabau. See Pires (1944: 164). This usage indicates الثموطرة must be translated not as Sumatra but as Samudera, as it clearly refers not to the entire island (in which Priaman was also located) but to the area of the kingdom of Samudera-Pasai.

${ }^{24}$ This must be the term mentioned by Peter Mundy in his account of Aceh: 'a Turon or tay is 4 Ryall of $8 \mathrm{tt}$ eight, no coin but a valuation'. The form 'turanae' is also attested, see Temple (1919: 136 and note 2).

${ }^{25}$ The 1516-17 Portuguese translation has omem mujto honrado que se chamaua panjcal. The discrepancy between the Portuguese and Arabic forms of the name is not easily explained. The second consonant in the Arabic is fairly clearly a $r \bar{a}^{\prime}$, and the final consonant also: it is quite different from the large clear final lams we see elsewhere in the letter.

${ }^{26}$ The 1516-17 Portuguese translation understands this rather as four of Birakir's men were killed along with him; in so far as sense can be extracted from the Arabic, however, that is not what it says.

${ }^{27}$ The term marq.sh given in the text is not Arabic. Taqiyuddin Muhammad's suggestion of reading Marrakesh is incredible, especially given the Arabic spelling of the city is quite different: مر اكش Alves (1999) suggests the Malay term markas, meaning caserna, quartel militar is meant; however such a word is not found in Wilkinson (1901), the standard reference for pre-modern Malay, suggesting its usage in this sense may be rather later than our period. Indeed, according to Stevens and Schmidgall-Tellings (2009), markas is in fact an Arabic word, presumably from Arabic markaz. In any event, the interpretation markas fails to account for the final shin which is clear in the ms. The 1516-17 Portuguese translation makes better sense, interpreting it as em outra tera mjnha que se chama marques. This suggests that marq.sh could be the name of a region; but to my knowledge no region with such a name (i.e. Markas or similar) is historically attested in north Sumatra. A final possibility is that the word is an Arabic transcription of the Portuguese word marcas, meaning 'frontiers, boundaries', in which the final s would be pronounced $\int$. This explanation has the merit of explaining the final shin and with fitting with the rough understanding of the contemporary Portuguese translator.

${ }^{28}$ L.b.s.t.y.ng. Alves/dos Santo have 'for his servant' (para seu criado). I do not see how this can be derived from the text. The 1516 Portuguese translation gives pedra, espravos, 'stones, slaves'.

${ }^{29}$ The bahar apparently equalled four old Portuguese quintals. See Barbosa (1918-1921, vol. 1: 157). 
from them one hundred /17/ tornayat of dirhams. His third [deed]: there came to Samudera a tarrād from Pulicut ${ }^{30}$ - that is, Nati ${ }^{31} / 18 /$ - with much wealth of the people of Sumatra. He took a hundred tornayat of dirhams from them /19/ by force and violence. His fourth [deed]: there came to Samudera a tarrād from Nawur ${ }^{32}$ - that is Nati - from which he took one hundred tornayat of $/ 20 /$ dirhams and twenty and a half dirhams. His fifth [deed]: there came to Samudera ship from Barus ${ }^{33} / 21 /$ which contained wealth belonging to the sultan of Bengal, from which he took a hundred bahar of $\operatorname{tin}^{34}$ and $4000 / 22 /$ pardãos ${ }^{35}$ and he sold all the people on this ship [into slavery]. His sixth [deed]: how many of the people of Samudera has he seized the wealth $/ 23 /$ by force and violence! And how many qadis and viziers have got angry with him because of this. We complain /24/ of our situation to you, for in our hearts [we know] that this has not been ordered by the king of Portugal, /25/ nor by you. The king does not know of these deeds of Manuel Falcão and Gaspar Machado. Because we know that the king and capitam mor do not wish for his port to be damaged, for our port is your port and you should protect it.

(c) Portuguese translation of the Arabic text, probably made in Malacca in 1516, transcribed by Pedro Pinto ${ }^{36}$

tralado de huma carta que manda el Rey de çamatra pera o gouernador esprita em papel de letra de parse

Eu esprevo a uosa Senhoria por boa vontade como amjgo el Rey de çamataram com aJuda de deus estou por Rej da tera ${ }^{37}$ por boa vontade pera $\mathrm{o}^{38}$ capitam mor Eu estou neste castelo d el Rej de portugall e toda mjnha tera estam debaxo da badeyra [sic] d el Rej ${ }^{39} \mathrm{de}$ portugal + faco saber nouas a carta que me mandastes ca sem nouas de vos folgej mujto com

\footnotetext{
${ }^{30}$ Portuguese translation of 1516: palyacate. Palicut or Pulicut is a port north of Madras on the Coromandel Coast of India where there was a Portuguese factory; at this date it was subject to the Empire of Vijayanagar. Barbosa (1918-1921, vol. 2: 129-32) notes its trade with Sumatra.

${ }^{31}$ The meaning of this word is unclear. Its repetition in line 19 suggests it is not a place name. It may refer to the name of some of the Muslims of the west coast of India, the Navayats, or in Port uguese, Naiteas, who claimed Arab origins, and who played an important role in shipping. See further Barbosa (1918-1921, vol. 1: 187, n.1); Pearson (1981: 123-4). 'Nati' in our text is thus probably to denote Muslim. The difficulty with this interpretation for this line is that Pulicut is an east coast not a west coast city.

${ }^{32}$ Probably Honnavar, which is mentioned in the Periplus of the Erythrean Sea as Naour, on the Malabar coast of India, and referred to by Ibn Battutaas Hunāwar. See Barbosa (1918-1921, vol. 1: 185ff). However, the 1516 Portuguese translation explains it as huma não de churomandel ('a ship of Coromandel'), although the name of the city is absent.

${ }^{33}$ The reading in the text is clear enough: $b-r-w-w-s$. Taqiyuddin Muhammad (2013) interprets this as the Sumatran port of Barus; but Alves (1999) suggests Broach in India. The Portuguese is of no assistance. While an Indian city might be suggested by the fact the boat belongs to the king of Bengal, Broach is on the other side of India and so it is no more likely that a ship from there would have a connection to Bengal than one from Sumatra. If the cargo was indeed tin, then Barus would be a logical origin for it (see note 34 below). Most likely, then, it was a ship belonging to the king of Bengal that was returning from Sumatra.

${ }^{34}$ The text's reading of $q a \bar{a}^{\prime} \bar{a}$ is difficult. I suggest this interpretation of 'tin' or possibly 'pewter' based on

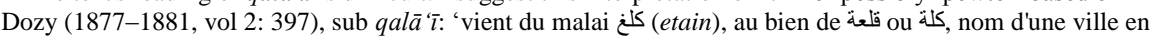
Inde d'ou l'on tirait l'étain, et a la fois un adj. et un subst., étain'. Tin was a well known commodity from the Sumatran interior, see for instance Andaya (2010: 40). However, tin would usually be written kaling in Malay rather than kalang which is suggested by the penultimate alif. Nonetheless, the reading is confirmed by the 1516 Portuguese translation cem bahares de chumbo ('100 bahars of lead/pewter'). The translator seems to have understood that some sort of metal was at stake.

${ }^{35}$ This interpretation is given by the 1516 Portuguese translation, and I cannot better it. However, I can offer no explanation of the term used in the Arabic text, jūn.

${ }^{36}$ Lisbon, Arquivo Nacional Torre do Tombo, Fragmentos, Caixa 2, Maço 2, Doc. 114

${ }^{37}$ Erased: 'per'.

${ }^{38}$ Erased: 'Senhor'

${ }^{39}$ Erased: 'd el'.
} 
elas e com a carta e asy como sempre fomos amjgos seJa asy sempre + qualquer omem portugueses que mandardes a mjnha tera se lhe fara mujto honra e cortesya e lhe darey presente,, e enquanto vyuer nunqua hej de quebrar de uosa amjzade,, veo huum capytam a mjnha tera que se chama manoel falquam e foy mujto maão pera toda mjnha tera e gente f[oj] a huma tera mjnha que se chama cureaz [...] / [fól. 1v. ${ }^{\circ}$ ] huma não dos mercadores de mjnha tera tomaram xxx pesoas que nela vynha e todos venderam e todos os outros mataram

E depois desta veyo huma não de bangala e tomaram lhe $\mathrm{ij}^{\mathrm{c}} \mathrm{xx}$ tondayas $\mathrm{d}$ ouro $\mathrm{e}$ tomaram huma molher,

E despoys desta veyo outra não d el Rej de bangala a tratar a mjnha tera e tomo a no camjnho e levo a pera melaqua nesta não todos os mercadores de mjnha tera tynham mujta fazenda nela nam sey como la pasou

E mays huum omem mujto honrado que se chamaua panjcal mataram no dentro em mjnha tera com quatro cryados seus,

item em outra tera mjnha que se chama marques me mataram dous omes,,

E mais me tomou este capitam dentro em mjnha tera ${ }^{40}$ outras - $\mathrm{ij}^{\mathrm{c}}$ tondayas $\mathrm{d}$ ouro, e pedra me [sic] L espravos e afora este me tomaram outro [sic] L escrauos os levaram pera melaqua e depoys me pediram L bahares de pimenta este capitam que veya [sic] a mjnha tera foy dyabo pera mjm

E despojs dysto vynha huma nãoo dos [sic] Jlha com cayro e Roupa mjnha lhe tomou outras $\mathrm{ij}^{\mathrm{c}} \mathrm{xx}$ tondayas d ouro / [fol. 2]

E depois desta vynha huma não de canbaya e chama se o seu dono alyxande e tomaram lhe cem tondayas d ouro,

E depois veyo huma não de palyacate com mujta fazenda dos mercadores de mjnha tera tomaram toda a gente e meteram na em huum troquo [sic] e tomaram lhe outras cem tondayas d ouro e soltaram a gente

E depois desta não veyo huma não de churomandel que trazya seguro e tomaram lhe cento e $\mathrm{xx}$ tondayas d ouro e mea,

E despois vejo outra não d el Rej de bangala que vynha pera mjnha tera e tomaram lhe cem bahares de chumbo e mais lhe tomaram quatro mill pardaos e toda a gente tomaram e a venderam e toda mjnha gente se trata mall e lhe dam mujtas pancadas e os Regedores de mjnha tera toma nos e os metem em o troquo e por amor de todos estas cousas que me fazem faço queyxume a uosa senhorja

pareçe me em mjnha vontade que el Rej de portugal nem uosa senhorja me nam mandaram fazer tal cousa e pareçe me que mo nam faz outrem nenhum senam esta gente nam poso entender por que me fazem Jsto $\left.2 \mathrm{v}^{\circ}\right]$

Jsto tudo me faz manoel falquam e gaspar machado que aquj estaua por fejtor / [fol.

Este meu porto e toda mjnha tera tudo he d el Rej de portugal fazem honra ao meu porto e sera mjnha honra e d el Rej de portugal

Eu nam sam poderoso pera poder fazer bem a el Rej de portugal el Rej me pode fazer grande Senhor,

Eu vos mandarey embaxador com presente pera uosa senhorja e esta he verdade

(2) The Acehnese letter to Queen Elizabeth I of England, 1603

(a) Transcription of the English translation by William Bedwell ${ }^{41}$

\footnotetext{
${ }^{40}$ Erased: 'ijc'.

${ }^{41}$ TNA, Kew, CO 77/1, ff.38r-39r. The translation, with some minor differences and omitting the marginalia, was originally published, with the letter from Elizabeth to the sultan of Aceh, in Purchas 1625, and reprinted in Shellabear (1898: 109-10). A rough version of Bedwell's translation, with some additional notes on the Arabic vocabulary, can be found in a manuscript held in the British Library: Cotton MS Nero B XI, fol. 79r-81r. I am very grateful to Annabel Teh Gallop for drawing my attention to these documents.
} 


\begin{tabular}{|c|c|c|}
\hline $\begin{array}{l}\beta \text { التَرَاق Arach, } \\
\text { Hortulus } \\
\text { geographicus } \\
\text { parte } 3^{\text {a }} \\
\text { climatis I } \\
\text { sayth that } \\
\text { ilPhorat, } \\
\text { that us, } \\
\text { Euhrates } \\
\text { nameth by } \\
\text { Arak. Plancius } \\
\text { saith, that } \\
\text { Arach was } \\
\text { aunciently } \\
\text { called } \\
\text { Partheia; others } \\
\text { Carmania, } \\
\text { others } \\
\text { Narsringa a } \\
\text { part of India } \\
\text { Therefore I }\end{array}$ & $\begin{array}{l}\text { Glory be to God, who hath magnified himselfe in his workes. } \\
\text { Glorified his dominion, Ordeyned kinges and kingdomes, } \\
\text { Exalted himselfe along in power and maiestie, He is not to be } \\
\text { uttered by word of mouth, Nor conceivd by imagination of ye } \\
\text { heart, He is no }{ }^{\gamma} \text { phantasma, No bound maye conteine him, } \\
\text { Nor any simlitude expresse him, His blessinge and peace is } \\
\text { over all goodnesse in the creature, Who hath bene heretofore } \\
\text { proclaimed by his prophets, And move againe since that } \\
\text { often, And last of all at this present by this writing, which } \\
\text { cannot be equalled. } \\
\text { For this }{ }^{\alpha} \text { Kingdome which is not slacke to shew their love, } \\
\text { hath declared it in the enterteinment of that societie which } \\
\text { filleth the horizont with joye, and in declaring it to the eie } \\
\text { [eye] by a signe which bringeth knowledge generally and } \\
\text { particularly, And for their request is [just]iust, with purpose } \\
\text { for exchange, And they themselves of honest behaviour, And } \\
\text { their love great in doing good to the creatures in generall, } \\
\text { Helping the creature in adversity and prosperity, Giving } \\
\text { liberally unto the poore and such as do stand in need of their } \\
\text { aboundance, Preserving the creatures to their uttermost, } \\
\text { which for them nowe is extended unto India and }{ }^{\beta} \text { Arak, } \\
\text { sending forth the cheefest men of discretion and note, using } \\
\text { also the best advise herein: } \\
\text { xAfrangi is an enemie to you, and an enemie to your } \\
\text { company in what place so ever he be from the first untill this } \\
\text { time. Yet what is he, beside his exceeding greate pride and } \\
\text { haughty minde. In this therefore is our joye encreased, and } \\
\text { our society confirmed, for that he \& his subjectes are our } \\
\text { And this is the } \text { sultan which dothe rule in } \psi \text { England, } \\
\text { Fraunce, Holland \& Fransuzze, God continue that kingdome } \\
\text { and empire longe in prosperity. } \\
\text { And for us as much as you do recorde that in your letters are } \\
\text { commendations to us. } \\
\text { kinge of } \varphi \text { Ashey who doth rule there with an absolute } \\
\text { dominion, is a man generally well reported of. } \\
\text { And for that there is spread a fame of you very pleasing by } \\
\text { the mouth of Captaine Jeames Lancaster, God continue his } \\
\text { welfare longe. }\end{array}$ & 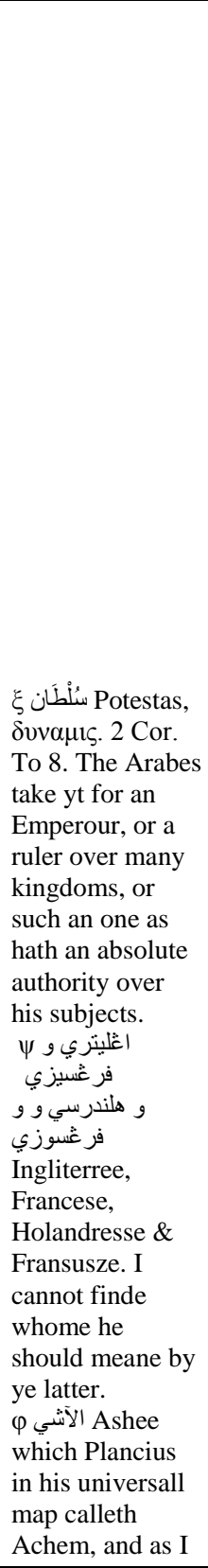 \\
\hline
\end{tabular}

${ }^{42}$ There is a tear in the text at this point. 


\begin{tabular}{|c|c|c|}
\hline $\begin{array}{l}\text { m. الحضرة العلي As before I } \\
\text { have observed } \\
\text { and they ? not } \\
\text { in such there } \\
\text { letters to } \\
\text { nominate ye } \\
\text { name of a } \\
\text { prince but } \\
\text { generally the } \\
\text { country. N. Or } \\
\text { thus a Ring of } \\
\text { gold beautified } \\
\text { with تلياقوت } \\
\text { which they } \\
\text { take in divers } \\
\text { senses. } \\
\text { q. خ̈rich. } \\
\text { i. Epoch or or } \\
\text { aera, a } \\
\text { beginning of } \\
\text { time from } \\
\text { whence was } \\
\text { begin to counte } \\
\text { as we from } \\
\text { Christ those } \\
\text { from Mahomet }\end{array}$ & $\begin{array}{l}\text { enemies in this world and the world to come, so that wee } \\
\text { shall condemme them to dye a publique death in what place } \\
\text { wee shall meete them, } \\
\text { And for that you do affirme. That you do desire peace and } \\
\text { freendshippe with us, to God be praise and thankes for the } \\
\text { greatnes of his grace, This is our serious will and honourable } \\
\text { purpose constantly, in this writinge, That from hence forth } \\
\text { you shal send from your company unto our kBander to trade } \\
\text { and to trafficke. } \\
\text { And that whosoever shall come unto us in your name, and } \\
\text { you shall assigne the time unto, shalbe of joynt company and } \\
\text { of common privileges. For wee have made this Captaine and } \\
\text { his company, as soone as as they came unto us of absolute } \\
\text { society and we have incorporated them into one corporation } \\
\text { and common privileges, } \\
\text { And wee have graunted them freedomes and have shewed } \\
\text { unto them the best waye of trade and trafficke, } \\
\text { And to manifest unto men, the love and brotherhood between } \\
\text { us and you in this world there is sent by the hand of this } \\
\text { Captaine ente yecordinge to the custome, unto the most } \\
\text { famous City, na Ringe beautified with a Rubie, richly placed } \\
\text { in his seate of gold, two Vestures woven with gold and } \\
\text { embroidered with gold, place within a purple boxe of China. } \\
\text { Written in qepocha anni } 1011 \text {. Vale. }\end{array}$ & $\begin{array}{l}\text { think they call it } \\
\text { in the other } \\
\text { quarters } ه \text { ا الافر Alafrangi } \\
\text { Ache. } \\
\text { x } \\
\text { Hortulus } \\
\text { geographicus in } \\
\text { clims. sayth a } \\
\text { very high } \\
\text { mountain called } \\
\text { Bartam doth } \\
\text { parte Andalusia } \\
\text { \& ye Alafrangia. } \\
\text { And he divideth } \\
\text { Burgundy into } \\
\text { Burgundy of ye } \\
\text { Almanes \& the } \\
\text { Burgundy of the } \\
\text { Alafrangi. } \\
\text { Therefore it } \\
\text { seemeth to be ye } \\
\text { parte of Spain } \\
\text { which they call } \\
\text { Castalia nueva. } \\
\text { k. worde, as I } \\
\text { thinke, but rather } \\
\text { a worde of the } \\
\text { language of } \\
\text { Samuddara or } \\
\text { Sumatra: for I } \\
\text { am informed ye } \\
\text { بن banda } \\
\text { signifieth } \\
\text { amongst them a } \\
\text { Country or } \\
\text { territory of } \\
\text { which I suppose } \\
\text { plumber }\end{array}$ \\
\hline
\end{tabular}

(b) Transcription of the extant parts of the Arabic text (Figure 2) (3) $^{43}$

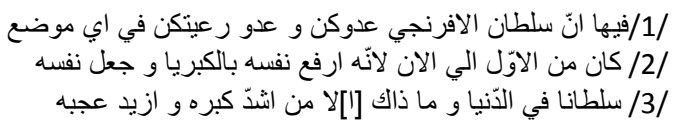

${ }^{43}$ MS Bodleian MS Douce Or.e.5 probably in the hand of William Bedwell; previously reproduced in Shellabear (1898), opposite p. 113. 


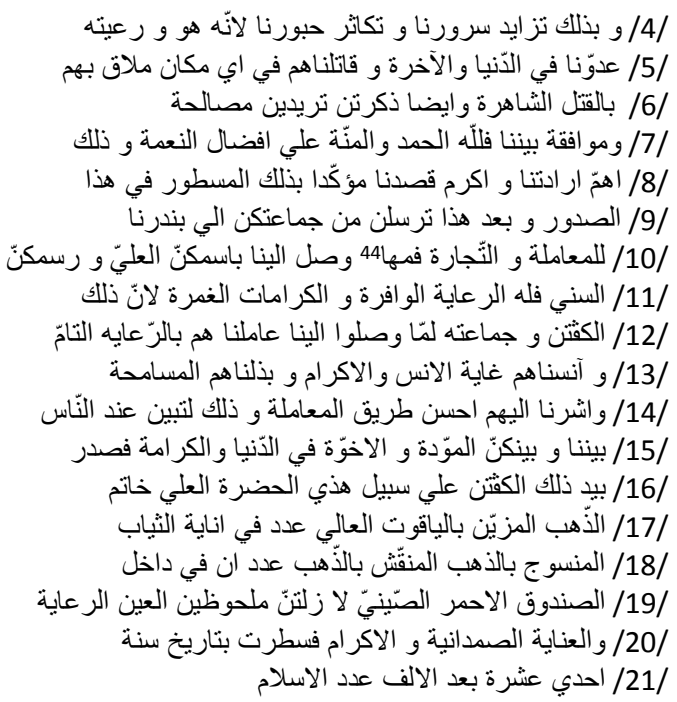

(c) Translation of extant Arabic text by A.C.S. Peacock

In it [the letter] [it was stated that] the sultan of Ifranji is your enemy and the enemy of your subjects in any place/2/, from the first until now, for he has raised himself up with arrogance and made himself $/ 3 /$ a ruler [or authority or sultan: sultan] in the world. There is no reason for that but his extreme presumption and excessive vanity./4/ For that reason our happiness was increased and our delight multiplied, for he and his people $/ 5 /$ are our enemies in this world and the next, and we have fought them /6/ openly in every place we have met them. You also mentioned in [the letter] that you desire a peace treaty /7/ and an agreement between us. Praise and blessings be to God for conferring blessings, for that is /8/ our most important desire and our dearest aim, affirming with this letter $/ 9 /$ its promulgation. After this you shall send your [members of] your company/group $/ 10 /$ to our port to do business and to trade. Any one of it who reaches us in your exalted name and your /11/ sublime document [of authority], shall have ample protection and abundant privileges, for that /12/ captain and his company, when they reached us we dealt with them with complete protection, /13/ and we were on very familiar and hospitable terms with them. We offered them tolerance /14/ and indicated to them the best way of doing business, that the friendship and fraternal relations $/ 15 /$ between us and you in this world and the next might become clear to people. Therefore, according to the custom of this high court, there was sent $/ 16 /$ by the hand of that captain a ring $/ 17 /$ of gold decorated with superb rubies ITEM, in its container, robes /18/ woven with gold, decorated with gold TWO ITEMS, /19/ inside the red Chinese chest. May you remain protected by the eye of the lord [God]/20/ and the eternal care and kindness.

/21/ Written in year 1011 of the Islamic calendar.

${ }^{44}$ Thus the ms, but in this instance most likely a copying mistake by Bedwell for fa-man فم man فيها فمن. 
(3) Letter from 'Ala' al-Din Riayat Syah of Aceh to Prince Maurice of the Netherlands, 1603 (Figure $3)^{45}$

(a) Arabic text

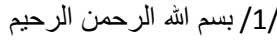

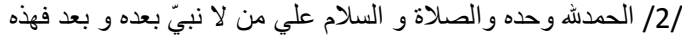

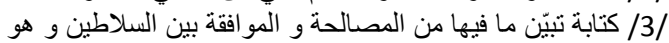

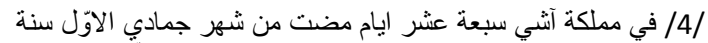

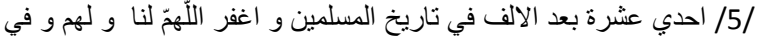

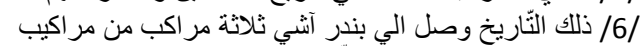

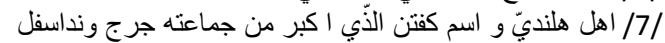

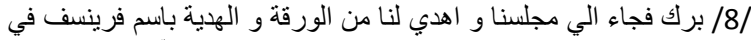

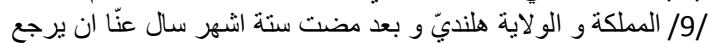

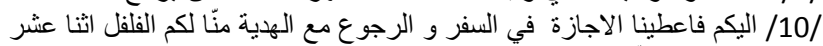

$$
\begin{aligned}
& \text { /11/ ابهرة آثني الّا النّصف تاريخه شهر شوّال سنة احدي عشرة بعد الآلف في عدد الإسلام }
\end{aligned}
$$

(b) Translation

/1/ In the name of God the Merciful and Compassionate. /2/ Praise be to God alone, and peace and blessings upon him after whom there is no other Prophet [i.e. Muhammad]. /3/ The contents of this letter announce the peace treaty and agreement between sultans, done /4/ in the kingdom of Aceh on 17 Jumada I in the year /5/ 1011 in the Muslims' calendar, may God forgive us and them. On /6/ that date there arrived in the port of Aceh three ships /7/ belonging to the people of Holland. The name of the captain who was the senior of the group was Georg van de Spil/8/berg[en]. He came to our court and presented us with letters and gifts in the name of the Prince $/ 9 /$ in the kingdom and province of Holland. After six months had passed, he asked us to return /10/ to you, and we granted him permission to travel and to return with presents for you from us, eleven /11/ and a half Acehnese bahar of pepper. Dated Shawwal year 1011 in the Islamic calendar. in the Islamic calendar.

Seal of Alauddin Riayat Syah ${ }^{46}$

\section{Figure captions:}

Figure 1 The letter from Sultan Zayn al-'Abidin IV of Samudera-Pasai, 1516-17. Document provided by Arquivo Nacional Torre do Tombo, Lisbon Code: Colecção de cartas, Núcleo Antigo 891, mç. 1, Doc. No. 59.

Figure 2 Arabic text of the letter of Sultan Alauddin Riayat Syah of Aceh to Queen Elizabeth I, 1602; fragments of a copy probably in the hand of William Bedwell. MS Bodleian MS Douce Or.e.5. Courtesy of the Bodleian Libraries, University of Oxford.

Figure 3 Letter from Alauddin Riayat Syah of Aceh to Prince Maurice of the Netherlands, 1603. Royal Archives (Koninklijk Huisarchief), The Hague, inventory number A13-XIB.

\section{Acknowledgements}

${ }^{45}$ Previous publication: Wassing-Visser (1995: 34-5), photograph and English translation. This translation contains several inaccuracies.

${ }^{46}$ For the reading of the seal, see Gallop 2004: 187. 
I am very grateful to Annabel Teh Gallop for first drawing my attention to the documents discussed here, and for comments on drafts of this paper, to Jorge Manuel dos Santos Alves for his assistance and discussion, and to Pedro Pinto for assisting with procuring a copy of the Pasai letter and for kindly agreeing to make available his transcription of the contemporary Portuguese translation for publication here. I would also like to thank the Torre de Tombo, Lisbon, the Bodleian Library, Oxford, and the Royal Archive, The Hague, for permission to reproduce documents from their collections.

\section{Author biography}

A.C.S. Peacock is Reader in Middle Eastern Studies in the School of History, University of St Andrews. Email: acsp@st-andrews.ac.uk.

\section{References}

\section{Archives}

Arquivo Nacional Torre do Tombo, Lisbon.

Colecção de cartas, Núcleo Antigo 891, mç. 1, Doc. 59 (Arabic letter of Sultan Zayn alDin of Pasai, 1516);

Fragmentos, Caixa 2, Maço 2, Doc. 114 (Portuguese translation of Arabic letter of Sultan Zayn al-Din of Pasai, c. 1516).

Bodleian Library, Oxford. MS Douce Or.e.5 (fragment of transcription in a European hand of Arabic letter of Sultan Alauddin Riayat Syah to Elizabeth I, 1602, probably transcribed by Bedwell)

British Library, London. Cotton MS Nero B XI, f. 79r-81r (rough draft of Bedwell's English translation of Arabic letter of Sultan Alauddin Riayat Syah to Elizabeth I)

National Archive (TNA), Kew.

CO 77/1, ff.38r-39r (final draft of Bedwell's English translation of Arabic letter of Sultan Alauddin Riayat Syah to Elizabeth I);

CO 77/14, f. 38 (Arabic letter from sultan Abu 1-Fath of Banten to Charles II, late December 1680);

CO 77/14, f. 111 (Arabic letter from sultan Abu 1-Fath of Banten to Charles II, November 1681).

Royal Archives (Koninklijk Huisarchief), The Hague. Doc no. A13-XIB (Arabic letter of Sultan Alauddin Riayat Syah to Prince Maurice of the Netherlands, 1603).

\section{Publications}

Agius, Dionysius. 2002. Classifying vessel types in Ibn Batțuṭa's Rihla. In Ruth Barnes and David Parkin (eds), Ships and the development of maritime technology in the Indian Ocean. London: Routledge, pp. 174-208.

Alves, Jorge Manuel dos Santos. 1999. O domínio do norte de Samatra: a historia dos sultanates de Samudera - Pacém e de Achém e das suas relações com os Portugueses (1500-1580) [The realm of north Sumatra : the history of the sultanates of SamuderaPasai and of Aceh and their relations with the Portuguese]. Lisbon: Sociedade Histórica da Independência de Portugal. 
Andaya, Leonard. 2010. Leaves of the same tree: trade and ethnicity in the Straits of Melaka. Singapore: National University of Singapore.

Atsushi, Ota. 2006. Changes of regime and social dynamics in West Java: society, state and the outer world of Banten, 1750-1830. Leiden: Brill.

Barbosa, Duarte. 1918-1921. The book of Duarte Barbosa: an account of the countries bordering on the Indian Ocean and their inhabitants, ed. and tr. Mansel Longworth Dames. London: Hakluyt Society (2 vols.).

Blagden, C.O. 1930. Two Malay letters from Ternate in the Moluccas, written in 1521 and 1522. Bulletin of the School of Oriental and African Studies 6 (1): 87-101.

Braginsky, Vladimir. 2004. The heritage of traditional Malay literature: A historical survey of genres, writings and literary views. Leiden: KITLV Press.

Broadbridge, Ann. 2008. Kingship and ideology in the Islamic and Mongol worlds. Cambridge: Cambridge University Press.

Brown, C.C. (trans). 1970. Sejerah Melayu, 'Malay Annals'. Kuala Lumpur: Oxford University Press.

Bruinessen, Martin van. 1995. Religious institutions in the Banten sultanate. Archipel 50: 16599.

Busse, Heribert. 1959. Untersuchungen zum islamischen Kanzleiwesen: an Hand türkmenischer und safawidischer Urkunden [Studies on Islamic chancery practice on the basis of Turkmen and Safavid documents]. Cairo: Kommissionsverlag Sirović Bookshop.

Casale, Giancarlo. 2005. His majesty's servant Lutfi: the career of a previously unknown sixteenth century Ottoman envoy to Sumatra. Turcica 37: 43-81.

Dozy, Reinhart. 1877-1881. Supplément au dictionnaires arabes. 2 vols. Leiden: Brill.

Foster, William (ed.). 1940. The voyages of Sir James Lancaster to Brazil and the East Indies 1591-1603. London: Hakluyt Society.

Gallop, Annabel Teh. 2003a. Bunga Setangkai: 'merely a single, withered flower', or a clue to the antiquity of the Malay letter-writing tradition? Indonesia and the Malay World 31 (91): 400-11.

Gallop, Annabel Teh. 2003b. Seventeenth-century Indonesian letters in the Public Record Office. Indonesia and the Malay World 31 (91): 412-39.

Gallop, Annabel Teh. 2004. Ottoman influences in the seal of Alauddin Riayat Syah of Aceh (r.1589-1604). Indonesia and the Malay World 32 (93): 176-90.

Gallop, Annabel Teh. 2007. Elevatio in Malay diplomatics. Annales Islamologiques 41: 4157.

Gallop, Annabel Teh. 2011. Gold, silver and lapis lazuli: royal letters from Aceh in the seventeenth century. In R. Michael Feener, Patrick Daly and Anthony Reid (eds), Mapping the Acehnese past. Leiden: KITLV Press, pp. 105-39.

Gallop, Annabel Teh. 2015. A Jawi sourcebook for the study of Malay palaeography and orthography: Introduction. Special issue. Indonesia and the Malay World 43 (125): 1339.

Gallop, Annabel Teh and Kratz, E. Ulrich. 1994. The legacy of the Malay letter-Warisan warkah Melayu. London: The British Library for the National Archives of Malaysia.

Gallop, Annabel Teh and Porter, Venetia. 2012. Lasting impressions: seals from the Islamic world. Kuala Lumpur: Islamic Arts Museum of Malaysia.

Gallop, Annabel Teh, Kadı. İsmail Hakk1 and Peacock, A.C.S. forthcoming. The language of letters: Southeast Asian understandings of Ottoman diplomatics. In İsmail Hakkı Kadı and A.C.S. Peacock (eds), Ottoman-Southeast Asian relations: sources from the Ottoman archives. Leiden: Brill. 
Gökbilgin, M. Tayyib. 1979. Osmanl paleografya ve diplomatik ilmi [Ottoman palaeogaphy and diplomatics]. Istanbul: Enderun Kitabevi.

Guillot, Claude and Kalus, Ludvik. 2008. Les monuments funéraires et l'histoire du sultanat de Pasai à Sumatra. Paris: Archipel.

Hadi, Amirul. 2004. Islam and the state in Sumatra: a study of seventeenth-century Aceh. Leiden: Brill.

Hamilton, Alastair. 1985. William Bedwell the Arabist, 1563-1632. Leiden: Sir Thomas Browne Institute.

Johns, A.H. 1996. In the language of the Divine: the contribution of Arabic. In Ann Kumar and John H. McGlynn (eds), Illuminations: the writing traditions of Indonesia. Jakarta: Lontar Foundation; New York: Weatherhill, pp. 33-48.

Jones, Russell. 1982. The first Indonesian mission to London. Indonesia Circle 28: 9-19.

Kad1, İsmail Hakk1, Peacock, A.C.S. and Gallop, Annabel Teh. 2011. Writing history: the Acehnese embassy to Istanbul, 1849-50. In R. Michael Feener, Patrick Daly and Anthony Reid (eds), Mapping the Acehnese past. Leiden: KITLV Press, pp. 163-81, 259-78.

Kad1, İsmail Hakk1 and Peacock, A.C.S. (eds). Forthcoming. Ottoman-Southeast Asian relations: sources from the Ottoman archives. Leiden: Brill.

Lambourn, Elizabeth. 2004. The formation of the Batu Aceh tradition in fifteenth-century Samudera-Pasai. Indonesia and the Malay World 32 (93): 211-48.

Ménage, Victor L. 1985. On the constituent elements of certain sixteenth-century Ottoman documents. Bulletin of the School of Oriental and African Studies 48 (2): 283-304.

Muhammad, Taqiyuddin. 2013. Naskah surat Sultan Zainal Abidin (Wafat 923H/1518M) [The manuscript letter of Sultan Zainal Abidin (died 923AH/1518AD)]. Al-Misykah: Berita kebudayaan Islam Asia Tenggara [Al-Misykah: news on Islamic culture in Southeast Asia]. <http://misykah.com/naskah-surat-sultan-zainal-abidin-wafat-923-h1518-m-2/> Accessed 23 June 2015.

Nieuwenhuijze, C. van. 1945. Sams 'l-Din van Pasai: bijdrage tot de kennis van de Sumatraansch Mystiek [S̆ams 'l-Din of Pasai: contribution to the study of the Sumatran mystic]. Leiden: Brill.

Pearson, Michael. 1981. Coastal western India: studies from the Portuguese records. New Delhi: Concept Publishing.

Pires, Tomé. 1944. Summa Oriental: an Account of the East, from the Red Sea to Japan, written in Malacca and India in 1512-1515, ed. and tr. Armando Cortesao. 2 vols. London: Hakluyt Society.

Pudjiastuti, Titik. 2007. Perang, dagang, persahabatan: surat-surat sultan Banten [War, trade, friendship: the letters of the sultans of Banten]. Jakarta: Yayasan Obor.

Purchas, Samuel. 1625. Hakluytus Posthumus, or Purchas his pilgrims. 4 vols. London: H. Fetherstone.

Reid, Anthony. 1969. Sixteenth-century Turkish influence in western Indonesia. Journal of Southeast Asian History 10 (3): 395-414.

Reinfandt, Lucian. 2013. Strong letters at the Mamluk court. National Research Network, Imperium and Officium Working Papers. Vienna: University of Vienna, <http://iowp.univie.ac.at/sites/default/files/IOWP_reinfandt_strongletters01.pdf> Accessed 27 November 2015.

Ricci, Ronit. 2011. Islam translated: literature, conversion and the Arabic cosmopolis of South and Southeast Asia. Chicago: University of Chicago Press. 
Santos, João dos. 1970. Documentos arabicos para a historia portuguesa [Arabic documents for Portuguese history]. Lisbon: Officina da Academia Real das Sciencias.

Shellabear, W.E. 1898. An account of some the oldest Malay mss now extant. Journal of the Straits Branch of the Royal Asiatic Society 31: 107-51.

Stevens, Alan M. and Schmidgall-Tellings A. 2009. A comprehensive Indonesian-English dictionary. Ohio: University of Ohio Press.

Temple, Richard Carnac (ed.). 1919. The travels of Peter Mundy in Europe and Asia, 16081667. Vol. 3, Part 1. London: Hakluyt Society.

Vrolijk, Arnoud. 2015. Scaliger and the Dutch expansion in Asia: an Arabic translation for an early voyage to the East Indies (1600). Journal of the Warburg and Courtauld Institutes 78: 277-309.

Wassing-Visser, Rita. 1995. Royal gifts from Indonesia: Historical bonds with the House of Orange-Nassau (1600-1938). The Hague and Zwolle: Stichting Historische Verzamelingen van het Huis Oranje-Nassau.

Wilkinson, R.J. 1901. A Malay-English dictionary. Singapore: Kelly and Walsh.

Wormser, Paul. 2014. La place des oulémas dans la société acihaise du XVIe au XXIe siècle [The place of the ulama in Acehnese society from the 16th to the 21st century]. Archipel 87: 7-28. 